\title{
使用中の合成樹脂製食器の規格試験並びに外観の 観察結果について
}

(昭和 60 年 12 月 16 日受理)

馬場二夫* 細川 守* 山田明男*

\section{Standards Inspection following Japanese Food Sanitation Law and the Evaluation of the Exterior of the Used Plastics Tablewares}

\author{
Tsugio BABA*, Mamoru HosoKawa* and Akio YAMADA* \\ (Osaka City Institute of Public Health and Environmental Sciences; \\ 8-34, Tojo-cho, Tennoji-ku, Osaka, Japan)
}

\begin{abstract}
Key words：合成樹脂製食器 plastics tablewares; 食品衛生法 Japanese Food Sanitation Law; 食器規格試験 tableware standards inspection; 溶出物 migrated substances; カドミウム cadmium; 過マンガン酸カリウム消費量 potassium permanganate consumption
\end{abstract}

\section{はじめに}

合成樹脂製の器具, 容器が一般家庭だけでなく学校, 会社, 病院等の集団給食施設, あるいは給食産業等に打 いて使用されるようになって久しくなる.これらの器 具, 容器は本来食品価生法にもとづく規格に適合したも ののみが使用されているはずであり，ことさら使用中の ものを対象として試験することは、これまでほとんど行 われていない1．しかし，合成樹脂製品は陶磁器製品等 と異なり, 光, 熱, 空気酸化その他の影響で次第に素材 が劣化することはよく知られている年 ${ }^{2)}$. 従って, 長期 間使用するものではその耐用期間, あるいは安全性に関 する知見が求められるところである. この度, 長期にわ たって使用されている合成樹脂製器具, 容器を対象とし て，規格の試験項目を中心に実態調査を実施したので， その結果の概要について報告する.

\section{実験方法}

1. 試料

対象とした試料は使用中の合成樹脂製器具, 容器で, 大阪市内の病院給食施設 8 力所, 事業所給食施設 10 か 所, 給食弁当調製施設10か所, 学校給食施設18か所及び 漬物製造業 5 か所から合計78種類 106 試料を収集した. 各施設から 1〜3 種類の試料を選択し, 1 試料当りそれ ぞれ 5 個ずつを入手した.ただし，漬物桶(容量約 $70 \mathrm{~L}$ ) については 1 試料につき 1 個を入手した.

*大阪市立環境科学研究所：大阪市天王寺区東上町 8 $-34$
試料の材質別内訳はポリプロピレン (PP) 製品19種類 28 試料, ポリェチレン (PE) 製品 5 種類, メラミン樹脂 (MF) 製品46種類, フェノール樹脂 $(\mathrm{PF})$ 製品 4 種類, ポリカーボネート (PC) 製品 3 種類 22 試料, ナイロン (PA) 製品 1 種類で, これら製品のうち表示から確認で きたメーカーは23社であった。

学校給食施設を除く33施設から収集した69試料の形態 別の材質及び使用年数の内訳は Table 1 に示したとお りである. 使用期間の最も短いものは 2 か月, 最も長い ものは 15 年で, 使用年数 $2 \sim 5$ 年のものが最も多い.

各食器の月平均使用頻度は 4 90 回で, 食器の洗浄方 法は手洗が12施設, 自動洗浄機使用が13施設, 手洗と自 動洗浄機両方で行っているところが 8 施設であった.

使用している洗剂は中性洗剤が18施設, アルカリ洗剤 8 施設, 無回答 7 施設であった。 また, 乾燥保管庫を備 えている施設の乾燥温度及び 時間の設定条件は， $60^{\circ}$, 30 分間のものから $100^{\circ}, 40$ 分, あるいは $80^{\circ}$, 17 時間 のものまで様々であった。

学校給食施設から入手した PP 製品 6 種類 15 試料, $\mathrm{PC}$ 製品 3 種類 28 試料については個別に調査できていな いが，全体として使用期間は 6 か月〜 6 年間である. 乾 燥保管庫はすべての施設が保有しており, ほとんどが $80^{\circ}$ ，30分間の設定条件で使用していた. 食器の洗浄方 法はすべて手洗と自動洗浄機の併用であった.

\section{2. 装}

原子吸光光度計：(株)島津製作所製，AA-640-12 型 
Table 1. Items of Sample Used in This Study Classified by Shapes, Materials, and Period of Use

\begin{tabular}{|c|c|c|c|c|c|c|c|}
\hline \multirow{2}{*}{ Sample } & \multirow{2}{*}{ Materials } & \multicolumn{6}{|c|}{ Period of use (Year) } \\
\hline & & $<1$ & $1 \leqq \sim<2$ & $2 \leqq \sim<5$ & $5 \leqq \sim<10$ & $10 \leqq$ & Total \\
\hline $\begin{array}{l}\text { Deep bowl } \\
\text { Rice-bowl }\end{array}$ & $\mathrm{MF}$ (15), PF (1) & 3 & 3 & 7 & 2 & 1 & 16 \\
\hline Dish & MF (23), PP (3) & 7 & 5 & 9 & 4 & 1 & 26 \\
\hline Tea cup & $\mathrm{MF}(3), \mathrm{PA}$ (1) & 1 & 0 & 2 & 1 & 0 & 4 \\
\hline Soup bowl & MF (5), PF (3) & 1 & 1 & 4 & 1 & 1 & 8 \\
\hline Lanch box & PP (10) & 0 & 3 & 5 & 2 & 0 & 10 \\
\hline Steeper & PE (5) & 0 & 1 & 3 & 1 & 0 & 5 \\
\hline Total & $\begin{array}{l}\mathrm{MF}(46), \mathrm{PF} \\
\mathrm{PP}(13), \mathrm{PE} \\
\mathrm{PA}(1)\end{array}$ & 12 & 13 & 30 & 11 & 3 & 69 \\
\hline
\end{tabular}

MF: melamine resine, PF: phenol resine, PP: polypropylene, PE: polyethylene, PA: polyamide (nylone), PC: polycarbonate

(The samples including PC obtained from school were excluded from this table)

自記分光光度計：(株) 島津製作所製, UV-240 型 ガスクロマトグラフ：日本電子(株)製, JGC-20K 型 粉研機: 日本精機 (株), 遠心式粉砕機, MZ-1 型

\section{3. 試薬}

カドミウム及び鉛標準溶液は原子吸光分析用（和光純 薬工業 (株) 製, $1,000 \mathrm{ppm}$ ) を使用時に適宜希釈して用 いた。

ホルムアルデヒド標準溶液はへキサメチレンテトラミ ン（特級）を水に溶かし，ホルムアルデヒドとして $0.01 \sim 1.0 \mathrm{ppm}$ に調製したものを用いた.

フェノール標準溶液はフェノール（特級）を水に溶か して $0.1 〜 10.0 \mathrm{ppm}$ に調製したものを用いた.

酶酸その他の試薬はすべて市販特級品を用いた. 水は イオン交換水を蒸留したものを用いた.

\section{4. 試験溶液の調製及び試験法}

各試料は洗剂で十分に污れを除去した後, 水洗し試験 に供した.

規格試験は厚生省告示第20号6) の方法に基づいて行っ た。ただし，漬物用桶については室温で24時間及び 7 日 間, 容器当り $3 \mathrm{~L}$ の溶媒を加えて放置し調製したものを 試験溶液とした。

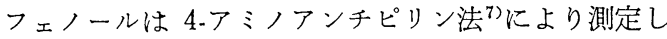
た.

$\mathrm{PF}$ 及び MF 製食器の場合, 規格では過マンガン酸カ リウム消費量の項目は除外されているが，本実験では他 の材質の試料との比較のため，これら樹脂製品について も測定した。

なお，結果はすべて試料の表面積と液量の比を $2 \mathrm{ml} /$ $\mathrm{cm}^{2}$ に掺算して示した.

\section{5. 試料の外観の肉眼による評価}

試料の内表面の污れ，傷，割れ・欠け，及び表面劣化
については肉眼的観察により $\mathrm{A}, \mathrm{B}, \mathrm{C}$ の 3 段階に区分 して評価した。 すなわち, 污れ, 傷, 及び割れ・欠けに ついては，それらがほとんどみられないものを $\mathrm{A}$ ，わず かにみられるがその程度が食器としての外観を損わない ものを $\mathrm{B}$ ，一見して明らかな污れ，傷，あるいは割れ・ 欠けがみられ著しく外観を損っているものをCとした. また，表面劣化については，滑らかで光沢があるものを A，光沢がかなり薄れ，表面の荒れがわずかにみられる ものを $\mathrm{B}$, 光沢が全く失われ，表面の荒れが著しいもの をCとした。

なお，污れは入手したままの状態の試料について観察 した.

\section{結果及び考察}

\section{1. 規格試験の結果}

厚生省告示第 20 号に基づく規格試験の結果は材質別分 類により Table 2 に示した. 材質試験, 溶出試験を通じ て 106 試料のらち，規格に不適合であったのはカドミウ ムを $1,250 \mathrm{ppm}$ 検出した PP 製弁当箱 1 試料のみで, 他はいずれも規格に適合していた。なお，材質試験にお いて PP 製弁当箱 2 試料及び MF 製飯わんからカドミ ウムをそれぞれ $3.1 \mathrm{ppm}, 11.7 \mathrm{ppm}, 2.5 \mathrm{ppm}$ 検出し, また， PA 製湯のみ 1 試料から鉛を $68 \mathrm{ppm}$ 検出してい る.これらはいずれも規格の基準值以下であるとはい え, 使用する添加剂の純度をはじめ成型時の品質管理が 重要である.また, 規格不適合の弁当箱の場合, 容器に 材質，製造業者名その他いっさいの表示がないものであ った，行政指導の立場からすれば，表示は使用開始後に おいても製造元等が確認できるような形態に改める必要 があるといえる。

次に, 溶出試験では重金属はすべての試料が 0.3 ppm 以下であった. 


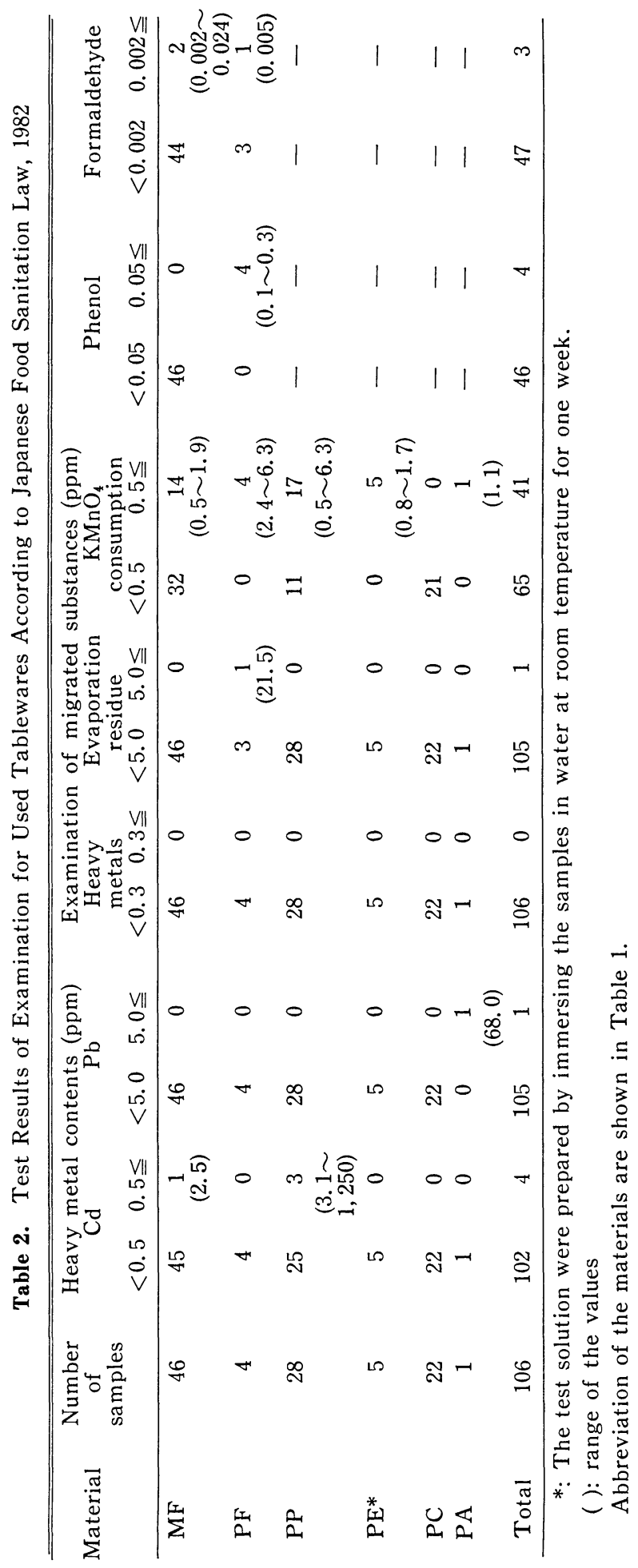


Table 3. Comparison of the Amounts of Migrated Substances from the Steepers with Immersing Periods

\begin{tabular}{crrrr}
\hline Sample & \multicolumn{2}{c}{$\begin{array}{c}\text { Evaporation } \\
\text { residue (ppm) }\end{array}$} & \multicolumn{2}{c}{$\begin{array}{c}\mathrm{KMnO}_{4} \\
\text { consumption } \\
(\mathrm{ppm})\end{array}$} \\
& $24 \mathrm{hrs}$ & 1 week & $24 \mathrm{hrs}$ & 1 week \\
\hline $\mathrm{a}$ & $<5.0$ & $<5.0$ & 0.3 & 0.8 \\
$\mathrm{~b}$ & $<5.0$ & 5.0 & 0.8 & 1.7 \\
$\mathrm{c}$ & $<5.0$ & $<5.0$ & 0.6 & 0.9 \\
$\mathrm{~d}$ & $<5.0$ & $<5.0$ & 0.3 & 0.9 \\
$\mathrm{e}$ & $<5.0$ & $<5.0$ & 0.3 & 0.9 \\
\hline
\end{tabular}

蒸発残留物は PF 製の汁わんの $21.5 \mathrm{ppm}$ 検出した もの 1 試料を除いて他はすべて $5.0 \mathrm{ppm}$ 以下であった.

過マンガン酸カリウム消費量は漬物桶を除く 101 試料 のうち65試料 (64.4\%) が $0.5 \mathrm{ppm}$ 以下であり, さらに $1.0 \mathrm{ppm}$ 以下のものは91試料 $(90.1 \%)$ であった. 1.0 $\mathrm{ppm}$ 以上のものは10試料で，その材質別内訳は $\mathrm{MF}$ 製 品が 46 試料中 3 試料 $(1.0,1.1,1.9 \mathrm{ppm}), \mathrm{PF}$ 製品は 4 試料全部 $(2.4,3.6,5.7,6.3 \mathrm{ppm}), \mathrm{PP}$ 製品は 28 試 料中 2 試料 $(1.4,6.3 \mathrm{ppm}), \mathrm{PA}$ 製品 1 試料 $(1.1 \mathrm{ppm})$ であった. $0.5 \mathrm{ppm}$ 以上検出した 41 試料の平均は 1.28 ppm であった.

なお,これら試料のうち MF 製食器 3 試料並びに PP 製弁当箱 1 試料は肉眼的にも著しい表面の劣化がみられ るものであった.

漬物用桶の蒸発残留物及び過マンガン酸カリウム消費 量の測定結果は Table 3 に示したとおりで, 蒸発残留 物は 24 時間浸漬したものも 7 日間浸漬したものもすべて $5.0 \mathrm{ppm}$ 以下であった. 過マンガン酸カリウム消費量 は24時間浸漬したものより 7 日間浸漬したものの方がい ずれの試料でも多くなっており, 溶出量におよぼす浸漬 時間の影響がみられた。

フェノールは PF 製品 4 試料すべてから検出され，そ の溶出量は $0.1 〜 0.3 \mathrm{ppm}$ であった. $\mathrm{MF}$ 製品でフェノ ールを検出するものはみられなかった.

ホルムアルデヒドは MF 製品 2 試料から 0.002 , 及び $0.024 \mathrm{ppm}, \mathrm{PF}$ 製品 1 試料から $0.005 \mathrm{ppm}$ 検出され た.

PF 及び MF 製品については, 数年にわたり使用した ものでもフェノールあるいはホルムアルデヒドが検出さ れている. これは樹脂の特性によるものと考えられるの で，使用にあたっては十分このことを考慮しておくこと が必要である.

なお，以上の各試料の中で過マンガン酸カリウム消費 量が比較的高い值を示した試料については, フェノー ル，ホルムアルデヒドなど一部由来の明らかなものを除 いて, それら溶出成分が樹脂由来のものか, あるいは食 品の成分で容器に浸透していたものが溶出してきたもの
Table 4. Results of the Evaluation of the Exteriors of 510 Tablewares by Visual Inspection

\begin{tabular}{lrrrrrr}
\hline \multirow{2}{*}{$\begin{array}{c}\text { Item of } \\
\text { inspection }\end{array}$} & \multicolumn{5}{c}{ Classification } \\
\cline { 2 - 7 } & \multicolumn{1}{c}{$(\mathrm{A})$} & \multicolumn{3}{c}{$(\mathrm{B})$} & \multicolumn{2}{c}{$(\mathrm{C})$} \\
& $(\mathrm{n})$ & $(\%)$ & $(\mathrm{n})$ & $(\%)$ & $(\mathrm{n})$ & $(\%)$ \\
\hline Stain & 370 & 72.6 & 121 & 23.7 & 19 & 3.7 \\
Scratch or Cut & 458 & 89.8 & 51 & 10.0 & 1 & 0.2 \\
Crack or Break & 452 & 88.6 & 45 & 8.8 & 13 & 2.6 \\
Deterioration & 481 & 94.3 & 28 & 5.5 & 1 & 0.2
\end{tabular}

A: The samples seemed as normal as new ones

B: The samples showed exteriors listed in the table

C: The samples remarkably, showed the list. ed exteriors

かについて検討することも必要と考える.

\section{2. 肉眼的観察による試料の外観評価}

入手した使用中の 106 試料各 5 個ずつ(浸漬桶は各 1 個）の合計 510 個 1 つ 1 つついて, 表面の污れ, 傷, 割れ・欠け，及び劣化の状況それぞれについて三段階評 価を行った結果は Table 4 に示したとおりである.こ れらの評価にあたっては，かなり主観的判断が入ること は避けられないが, 使用中食器の外観状況を表す指標の ないなかでの一つの試みとして行ったものである.

Table 4 に示したように, 污れに関しては判定区分B 及びCのものが 510 個のらち 140 個 (27.5\%) であった. 污れは入手先の施設によって集中的にみられる傾向があ り，入手した試料の半数以上が BまたはCと判別された のは 7 施設で, そのらちの 4 施設は病院であった.なお, 污れに関しこの集計とは別に，内面は比較的きれいだけ れども，外面が著しく污れたままの試料がかなりみられ た. 給食施設に拈ける食器の管理にあたっては,この点 についても改善が必要である. 傷, 割れ・欠け, 及び表 面劣化については B 及び $\mathrm{C}$ の評価区分の合計は，それぞ れ $10.2 \%, 11.4 \%, 5.7 \%$ であった.

入手した同一試料 5 個すべてが表面劣化の著しいもの も汁わん, 小判血, 弁当箱にそれぞれ 1 試料ずつみられ た.なお, 表面劣化のみられる試料の場合, それは容器 全体に一様にみられるのではなく, 食品と最もよく接触 している部分ほど顕著にみられた. このことから, 樹脂 の劣化には接触する食品の種類, 温度, 接触時間及び使 用回数などが影響するものと考えられる. 今回調査した 試料はそれらの条件がそれぞれ異なっており，さらに材 質の種類もさまざまであることなどもあって，単純に使 用年数の長いものほど劣化が進行しているといら傾向は みられなかった。 ちなみに, 前記劣化の著しい汁わんの 使用年数は 4 年, 小判皿, 弁当箱はいずれも 1.5 年と報 告されているものであった. 
I 事業所から入手したどんぶり (使用年数 1.5 年), 小 判 皿 (同1.5年)，小鉢 (同1.5年)の 3 試料の場合, 污れ, 傷, 割れ・欠け, 及び表面劣化のほとんどの指標におい てBまたはC 評価される状況のものであったことは， 規格の適否とは別に食器の管理上の改善が求められると ころである.なお，当該事業所から入手した試料の場合， 他と比較して使用年数が少ないにもかかわらず劣化をは じめとする外観的損傷が著しいが, 食器の使用頻度, 洗 浄方法, 保管方法等では他の事業所とそれ程異なってい ない.それ学，使用年数の報告が正確であったのかど らか, いささか疑問の残るところである.

学校の給食施設から入手した食器は前記のいずれの指 標についてもA 評価されるものが注とんどで，全般的 に衛生管理のゆきとどきがみられた。

以上の観察結果以外に, 給食用弁当調製施設で用いら れている弁当箱の中には，内側と外側を別々に成型し， 接着剂等で張り合せたものがいくつかみられた。 それら のなかには接着面がはがれていたり，ひび割れしたもの がかなりあり，そのすき間から洗剤を含んだ水がしみ出 してくるようなるのも数件みられた。 これは食品衛生に 関わる問題として留意する必要があるとともに, 成型法 についても工夫を要すると考える.

\section{まとめ}

病院, 事業所, 学校, その他の給食施設で使用中の $M F, P P$ 等の合成樹脂製食器（使用期間 2 か月～15年） 106 試料を対象として，厚生省告示第20号の規格にもと づく試験を行った，同時に食器の洗浄，保管条件及び使 用状況の調査, 並びに食器表面の污れ, 傷, 割れ・欠ケ, 劣化など外観状況についての肉眼的観察を行った。

1. カドミウム及び鉛の材質試験において規格の基準 值を越えたものは，カドミウムを $1,250 \mathrm{ppm}$ 検出した PP 製弁当箱 1 件のみであった。当該試料は製造元を確 認できる表示のない唯一のものでもあった.
2. 溶出試験では重金属, 蒸発残留物, 過マンガン酸 カリウム消費量, フェノール，ホルムアルデヒドのいず れの項目においても基準值を越えるものはなかった。な お，過マンガン酸カリウム消費量において $0.5 \mathrm{ppm}$ 以 上検出した試料は 41 件 $(38.7 \%)$ で，それらの平均值は $1.28 \mathrm{ppm}$ であった.

3. 食器の外観の污れ, 傷, 割れ・欠け, 及び表面劣 化について，それらが食器としての外観を損っていると 評価したものの割合は，それぞれ $27.5 \% ， 10.2 \%$, $11.4 \% ， 5.7 \%$ であった.これら 4 項目のいずれにおい ても管理が行届いていない給食施設もいくつかみられ た. 污れについては内面は比較的きれいだが外側が著し く污れたままのものがかなりみられた。

\section{謝辞}

本調査は昭和59年度大阪市環境保健局特別調查研究と して実施したものであり, 試料の収集その他において御 協力いただいた大阪市環境保健局食品衛生課並びに, 市 内各保健所の食品衛生監視員諸兄に深謝します。

文献

1) 馬場二夫, 他: “続食品容器包装器具衛生解説”, p. 207 219（1977） 日本衛生技術研究会.

2）栗原福次：“プラスチックの劣化”（1970）日刊工 業新閏社.

3）電気学会有機材料劣化専門委員会編：“高分子材 料の劣化” (1958) コロナ社.

4) M. B. ネイマン著, 稲葉弥之助, 飯山比呂美訳： “高分子の劣化一その機構と防止法一” (1967) 産 業図書.

5）鍵谷 勤，西本清一：高分子加工． 32, 15 20 (1983).

6）厚生省告示第 20 号，昭和57年 2 月 16 日付官報

7) 日本薬学会編：“衛生試験法・注解” p. $77 \sim 78$ (1980) 金原出版。 